\title{
Effects of moderate red wine consumption on liver fat and blood lipids: a prospective randomized study
}

\author{
Stergios Kechagias, Sepehr Zanjani, Solveig Gjellan, Olof Dahlqvist Leinhard, \\ Johan Kihlberg, Örjan Smedby, Lars Johansson, Joel Kullberg, Hakan Ahlstrom, \\ Torbjörn Lindström and Fredrik Nyström
}

\section{Linköping University Post Print}

N.B.: When citing this work, cite the original article.

Original Publication:

Stergios Kechagias, Sepehr Zanjani, Solveig Gjellan, Olof Dahlqvist Leinhard, Johan Kihlberg, Örjan Smedby, Lars Johansson, Joel Kullberg, Hakan Ahlstrom, Torbjörn Lindström and Fredrik Nyström, Effects of moderate red wine consumption on liver fat and blood lipids: a prospective randomized study, 2011, Annals of Medicine, (43), 7, 545-554.

http://dx.doi.org/10.3109/07853890.2011.588246

Copyright: Informa Healthcare http://informahealthcare.com/

Postprint available at: Linköping University Electronic Press http://urn.kb.se/resolve?urn=urn:nbn:se:liu:diva-71373 


\section{Effects of moderate red wine consumption on liver fat}

\section{and blood lipids: a prospective randomized study}

Running title: Effects of red wine on HTGC

Stergios Kechagias MD $\mathrm{PhD}^{1}$, Sepehr Zanjani $\mathrm{BM}^{1} *$, Solveig Gjellan $\mathrm{BM}^{1} *$, Olof Dahlqvist Leinhard $\mathrm{PhD}^{2,3}$, Johan Kihlberg R.N. ${ }^{3}$, Örjan Smedby MD Prof. ${ }^{3}$, Lars Johansson $\mathrm{PhD}^{4}$, Joel Kullberg $\mathrm{PhD}^{4}$, Håkan Ahlström MD Prof. , Torbjörn Lindström $\mathrm{MD} \mathrm{PhD}^{1}$, and Fredrik H Nystrom MD Prof. ${ }^{1,5} .1$ Department of Medical and Health Sciences, 2 Radiation physics, Faculty of Health Sciences, Linköping University. 3 Center for Medical Image Science and Visualization (CMIV) and Radiology, Linkoping University. 4 Department of Oncology, Radiology and Clinical Immunology, Section of Radiology, Uppsala University. 5 Diabetes Research Centre, Linköping University. Sweden. *These authors contributed equally to the study.

Funding: The study was supported by University Hospital of Linköping Research Funds, Linköping University, Gamla Tjänarinnor, Medical Research Council of Southeast Sweden, ALF grants from Östergötland County Council, the Diabetes Research Centre of Linkoping University, and the Swedish Research Council grant K2010-64X-08268-23-3.

Address correspondence to:

Fredrik H. Nystrom MD PhD professor

Department of Medical and Health Sciences

Faculty of Health Sciences

Linköping University

SE 58185 Linköping, Sweden

Telephone; +46 101037749

Fax; +4613145949

E-mail; fredrik.nystrom@lio.se 
Background: There have been no human prospective randomized studies of the amount of alcohol that can induce hepatic steatosis.

Methods: Thirty-two healthy women and 12 healthy men ( $34 \pm 9$ years of age) were randomized to consume $150 \mathrm{ml}$ of red wine/day for women $(16 \mathrm{~g}$ ethanol/d) or the double amount for men (33g ethanol/d), or to alcohol abstention during 90 days. Participants underwent proton-nuclear magnetic-resonance spectroscopy for measurement of hepatic triglyceride content (HTGC). Blood samples for assessment of cardiovascular risk were drawn before and after the intervention.

Results: After exclusion of three subjects with steatosis at baseline a trend towards increased HTGC was apparent by red wine (before median: $1.1 \%$, range $0.2-3.9 \%$, after median: $1.1 \%$, range $0.5-5.2 \%, \mathrm{p}=0.059$ ) a difference that was statistically significant compared with abstainers $(\mathrm{p}=0.02)$. However, no subject developed hepatic steatosis. LDL-cholesterol was lowered by red wine (-0.3 mmol/1, SE -0.1, 95\% CI -0.6 to -0.04). Conclusions: Moderate consumption of red wine during three months increased HTGC in subjects without steatosis at baseline. However, since not a single participant developed steatosis we suggest that the threshold of alcohol consumption to define nonalcoholic fatty liver disease should not be lower than the amount in our study.

Key words: NAFLD, alcohol, hepatic triglyceride content 


\section{Key messages}

- This study represents the first randomized trial of moderate alcohol consumption with a follow-up time regarded sufficient to evaluate changes in hepatic triglyceride content.

- The results of this study provide original information about the effect of moderate wine drinking on the hepatic triglyceride content.

- Consumption of alcohol which is higher than currently recommended by many authors for a diagnosis of nonalcoholic fatty liver disease did not induce hepatic steatosis. However, minor effects on hepatic triglyceride content and aminotransferases were noted. Moreover, this study confirms previous data indicating that hepatic triglyceride content is more strongly linked with components of the metabolic syndrome than with alcohol intake.

Abbreviations: NAFLD, nonalcoholic fatty liver disease; ALD, alcoholic liver disease;

HTGC, hepatic triglyceride content; CVD, cardiovascular disease; ${ }^{1} \mathrm{H}-\mathrm{MRS}$, proton nuclear magnetic resonance spectroscopy; NASH, nonalcoholic steatohepatitis; QBC, quadrature body coil; PRESS, point resolved spectroscopy; VOI, volume of interest; FID, free induced decay; HOMA, homeostasis model assessment; QUICKI, quantitative insulin sensitivity check index. 


\section{Introduction}

Moderate alcohol consumption, typically equivalent to 1 glass of wine/day for women and the double amount for men, has been linked with a favorable cardiovascular risk profile and low prevalence of cardiovascular disease (CVD) (1). Today there is worldwide concern about the steep rise in the prevalence of obesity which is likely to result in an ensuing increase in the prevalence of the metabolic syndrome, i.e. the combination of obesity, dyslipidemia, elevated levels of blood pressure and of blood glucose, which is strongly linked with CVD. The exact mechanisms behind the metabolic syndrome are not known, but a major culprit seems to be reduction of the metabolic effects of insulin, denoted insulin resistance (2). Results of prospective randomized trials with a duration up to a few months have suggested that intake of moderate amounts of alcohol induces an increase of HDL cholesterol levels $(3,4)$ and also reduces insulin resistance (5), while acute effects of alcohol intake are also related to vasodilation leading to lowered blood pressure. Thus, moderate alcohol intake seems to counteract many components of the metabolic syndrome, perhaps even the insulin resistance itself.

Accumulation of fat in hepatocytes, mainly in the form of triglycerides, is the most common hepatic pathology. Traditionally, hepatic fat content exceeding 5\% of liver weight has been considered the definition of fatty liver (steatosis). Recently, when hepatic triglyceride content (HTGC) was measured with proton nuclear magnetic resonance spectroscopy $\left({ }^{1} \mathrm{H}-\mathrm{MRS}\right)$ in subjects of the general population without apparent risk factors for hepatic steatosis, the $95^{\text {th }}$ percentile of HTGC was found to be $5.56 \%$, thus being in close agreement with earlier definitions of steatosis (6). When consumed excessively, alcohol can cause a wide spectrum of chronic liver injury from 
steatosis to steatohepatitis, steatohepatitis with fibrosis, and cirrhosis (7). In 1980,

Ludwig et al. coined the term nonalcoholic steatohepatitis (NASH)(8) and subsequently the more embracing term nonalcoholic fatty liver disease (NAFLD) has been established to cover the full spectrum of hepatic pathology associated with fatty infiltration in subjects without a history of excessive alcohol consumption. NAFLD is considered a hepatic manifestation of insulin resistance (2), and is accordingly associated with the metabolic syndrome (9). The prevalence of NAFLD is around 20$30 \%$ in the general population $(10,11)$ and it has been demonstrated that at least $5 \%$ of adults with NAFLD will develop end-stage liver disease (12). With a rapid increase in development of obesity and the metabolic syndrome, NAFLD has become the most common cause of liver disease in Western countries.

Alcoholic liver disease and NAFLD, which are both characterized by steatosis, cannot be distinguished morphologically. To separate the two conditions a cut-off limit for alcohol consumption is used. However, there is no consistent agreement regarding the amount of alcohol that is sufficient to induce steatosis. Authors differ on the level of alcohol consumption that can reliably distinguish between alcoholic steatohepatitis and $\mathrm{NASH}$, from total abstinence (as in the original descriptions) to $36 \mathrm{~g}$ ethanol/day $(8,13)$, and even to simplify by just excluding those with "alcoholism" has been suggested (14). Moreover, methods for obtaining an alcohol intake history vary, making it difficult to compare the results of different studies. In a recently published position statement on NAFLD/NASH based on the European Association for the Study of the Liver (EASL) 2009 special conference a daily intake of $<20 \mathrm{~g}$ in women and $<30 \mathrm{~g}$ in men is required for the diagnosis of NAFLD (15). However, the NIH clinical research network on NAFLD/NASH agreed that the maximum allowable level of alcohol intake for 
definition of NAFLD is two standard drinks a day (20 g ethanol/day) for men, and one standard drink a day (10 g ethanol/day) for women (16).

To our knowledge, no prospective randomized trial has been performed to ascertain whether HTGC is increased by moderate alcohol consumption or not. Therefore, we performed a prospective randomized study on the effects of 90 days of moderate wine drinking on levels of HTGC measured by ${ }^{1} \mathrm{H}-\mathrm{MRS}$, and in addition we studied the effects on liver function tests, traditional markers of CVD and insulin levels.

\section{Methods}

By local advertisement we recruited 46 potential participants who were willing to be randomized to either consume $150 \mathrm{ml}$ of red wine/day for women or the double amount for men, or to total alcohol abstention for 90 days during September to December of 2009. The participants were all free from significant diseases as judged by medical check-up and history at recruitment. Only participants without a history of psychiatric disease or alcohol abuse personally or among first degree relatives were recruited and the lowest allowed age for participation was 25 years. One female subject withdrew her consent shortly after screening for personal reasons and one potential male participant was at inclusion found to have a liver spectroscopy finding in accordance with hepatic iron excess. Subsequent diagnostic work-up confirmed genetic hemochromatosis and he was consequently not allowed to participate in the study. The remaining 44 participants displayed no signs of relevant diseases, and were randomized to either of the groups. The recruitment included three pairs of women and men living together and these couples were allowed to share the same randomization condition. The questions of the 
AUDIT-C questionnaire (17) and interviews were used to assess habitual alcohol consumption at study entry.

Participants that were randomized to alcohol abstention were asked to avoid any sort of alcohol intake during the three study months while those that were randomized to moderate consumption were asked to consume one glass of red wine $(150 \mathrm{ml})$ per day for women and the double amount for men. They were asked not to drink any extra alcohol than the red wine which could be consumed at any time during the day. However a general recommendation was given to consume the wine in the evening since many employers do not allow consumption of alcohol during working hours in Sweden. The red wine to be consumed was collected at the Department of Medical and Health Sciences and participants had 8 different wines to choose from. The wines, which were based on shiraz and cabernet sauvignon grapes, had an alcohol content of $13.5 \%-14 \% \mathrm{v} / \mathrm{v}$ and the daily alcohol intake thus was $16.0-16.5 \mathrm{~g}$ for women and 32-33 $\mathrm{g}$ for men, according to the protocol, among those who were randomized to alcohol ingestion. Subjects of the wine group were asked to drink the provided wines but were allowed to replace them temporarily with other wine that was offered, at for example dinners not eaten at home. They were asked to drink the prescribed amount of wine, no more no less, also when drinking under such situations. The participants were instructed not to change eating and exercise habits during the trial. Blood for laboratory tests was drawn in the fasting state at baseline, and after three months i.e. at the end of the study period.

The participants underwent ${ }^{1} \mathrm{H}-\mathrm{MRS}$ of HTGC by using a Philips Intera/Achieva $1.5 \mathrm{~T}$ MR-system (Philips Medical Systems, Best, The Netherlands) (18). The built-in system quadrature body coil (QBC) was used to acquire PRESS (point resolved 
spectroscopy) ${ }^{1} \mathrm{H}-\mathrm{MRS}$ spectra without water suppression from two different volumeof-interest (VOI) avoiding major blood vessels and bile ducts. The signal was averaged from three breath-holds using 8 averages in each following 2 dummy scans. The repetition time was $1500 \mathrm{~ms}$, the echo time was $35 \mathrm{~ms}$ and the voxel volume was 3x3x3 $\mathrm{cm}^{3}$. The water and lipid resonances were fitted in the time domain incorporating prior knowledge using the AMARES algorithm in the jMRUI software package $(19,20)$. This was done after truncation of the two initial data points in the free induced decay (FID) to improve the spectral baseline followed by frequency correction and summation of the spectra from the different breath-holds. The lipid volume fractions (HTGC) were calculated as previously described (18).

The participants filled out questionnaires for determination of well-being and the experience of the study and they were subjected to determination of body fat content with BodPod (Life Measurement Inc., Concord, CA, USA) equipment, at baseline and at the end of the trial. The blood pressure was measured in the supine position with an automatic device (Dinamap PRO 200, Critikon, Tampa, USA). Finally the participants underwent non-invasive analysis of flow-mediated vasodilation in the brachial artery, to be reported separately, before and after the trial. The study was registered at ClinicalTrials.gov (NCT00954434).

\section{Statistics}

Statistical calculations were done with PASW 18.0 software (SPSS Inc. Chicago, IL, USA). Linear correlations were calculated, as stated in the text. Comparisons within and between groups were done with Student's paired and unpaired 2-tailed t-test or as stated 
in the results section. Mean (SD) is given unless otherwise stated. Statistical significance was considered to be present at the 5\% level $(\mathrm{p} \leq 0.05)$. Since HTGC was non-normally distributed, non-parametric test were also used for calculations as stated (Mann-Whitney test and Spearman correlations, correlations given with rho values). The study had $86 \%$ power to detect an increase in HTGC in the red wine group compared with controls and 99\% power to detect development of liver steatosis (HTGC of $\geq 5.6 \%$ ) in the wine group, with the level of statistical significance set at $p \leq 0.05$.

\section{Ethics}

The study was approved by the Regional Ethics Committee of Linköping and performed in accordance with the Declaration of Helsinki. Written informed consent was obtained from all participating subjects.

\section{Results}

There were no dropouts during the study three month period. One male subject in the red wine group was not able to perform the ${ }^{1} \mathrm{H}-\mathrm{MRS}$ due to acute sense of claustrophobia, a predisposition which was previously unknown. Habitual alcohol consumption at baseline did not differ between groups (13 g/week, range 4-68 g/week in the group randomized to red wine, vs. $13 \mathrm{~g} /$ week, range 4-100 g/week in the group randomized to abstention; $\mathrm{p}=0.85$ by Mann-Whitney). All subjects randomized to the wine group markedly increased their alcohol consumption (range 1.63-56 times). On average, among subjects randomized to alcohol, women consumed 13.0 \pm 2.2 liters and men $27.9 \pm 4.9$ liters of wine delivered by the study organizers during the three month period. This amount corresponded to an average consumption of $16 \mathrm{~g}$ ethanol/day for 
women and $33 \mathrm{~g}$ ethanol/day for men. Table 1 shows major anthropometrics and laboratory variables before and at the end of the study period.

Levels of all variables were similar in both randomization groups at the start of the study. At baseline there was no correlation between habitual alcohol consumption and HTGC ( $r=0.01, p=0.94)$. No significant correlations were found between habitual alcohol consumption and GT $(r=0, p=0.98)$ and ALT ( $r=0.07, p=0.67)$. Baseline HTGC was significantly correlated with GT ( $r=0.90, p=0.0001)$, ALT $(r=0.62, p=0.0001)$, glucose ( $\mathrm{r}=0.52, \mathrm{p}=0.0001)$, HOMA $(\mathrm{r}=0.40, \mathrm{p}=0.009)$, LDL cholesterol $\mathrm{r}=0.51$, $\mathrm{p}=0.0001), \operatorname{ApoB}(\mathrm{r}=0.54, \mathrm{p}=0.003), \mathrm{CRP}(\mathrm{r}=0.47, \mathrm{p}=0.003)$, diastolic blood pressure $(\mathrm{r}=0.35, \mathrm{p}=0.02), \mathrm{BMI}(\mathrm{r}=0.54, \mathrm{p}=0.0001)$, sagittal abdominal diameter $(\mathrm{r}=0.48$, $\mathrm{p}=0.001)$, and body fat content $(\mathrm{r}=0.39, \mathrm{p}=0.01)$. When baseline variables were analyzed non-parametrically, correlation between HTGC and ALT was found to be statistically non-significant ( $\mathrm{rho}=0.27, \mathrm{p}=0.08$ ) while the opposite pattern was found for ferritin ( $r h o=0.38, p=0.01)$, all other correlations did not differ with respect to significance.

There were no changes induced by wine regarding body weight or body fat percentage, nor were the levels of insulin affected (Table 1), neither were levels of HOMA (21) marker of insulin resistance, or QUICKI (22) marker of insulin sensitivity (not shown). Resting blood pressure was $106 \pm 11 / 67 \pm 7.4 \mathrm{mmHg}$ at baseline in the abstention group and $108 \pm 12 / 66 \pm 9.6 \mathrm{mmHg}$ in the red wine group, and was unchanged during the study ( $\mathrm{p}$ for comparison of changes: 0.9 and 0.14 for systolic and diastolic BP, respectively).

There was an increase in the levels of ALT and AST in the red wine group and this change was statistically significant compared with the alcohol abstention group (ALT: 
+4.7 U/1, SE $1.8,95 \%$ CI 0.6 to 8.8 , AST: +4.1 U/1, SE 1.4, 95\% CI 1.3 to 6.9 , Table 1$)$.

The highest recorded levels of ALT and AST in the group randomized to wine after three months were $44 \mathrm{U} / 1$ and $39 \mathrm{U} / \mathrm{l}$, respectively. During the study period no subject developed levels of aminotransferases exceeding the upper limit of normal in Sweden (i.e. ALT: $65 \mathrm{U} / 1$ for men and $44 \mathrm{U} / 1$ for women, AST: $45 \mathrm{U} / 1$ for men and $36 \mathrm{U} / 1$ for women). Albumin levels were lowered by red wine consumption but there was no effect on bilirubin levels (Table 1).

There were no changes in the levels of HDL cholesterol or triglycerides during the trial. However, levels of LDL cholesterol were lowered within the group randomized to wine consumption and the change was statistically significant also when compared between the two groups $(-0.3 \mathrm{mmol} / \mathrm{l}, \mathrm{SE}-0.1,95 \% \mathrm{CI}-0.6$ to -0.04 , Table 1$)$. The levels of ApoA were lowered within both groups equally (Table 1).

Three subjects had HTGC exceeding 5.6\% at baseline (7.7\%, 8.2\%, and 22.1\%, respectively; Figure 1; observe that the Y-axis is logarithmic) thus fulfilling current criteria for hepatic steatosis. The subject with the highest HTGC at baseline was part of the red wine group, her HTGC was reduced to $14.6 \%$ after three months (see Figure 1). The other two subjects were randomized to abstention. In these subjects only minor changes in HTGC were noted at follow-up (increase to $8.3 \%$ and reduction to $6.5 \%$, respectively, see Figure 1). No participant developed hepatic steatosis during the study period. As can be seen in Figure 1 and in Table 1 daily consumption of red wine for three months had no statistically significant effect on HTGC either within the total red wine group or when compared with changes in subjects randomized to alcohol abstention (mean difference between groups: $0.2 \%$, SE $0.4 \%, 95 \%$ CI $-1.1 \%$ to $0.8 \%$ ). 
A

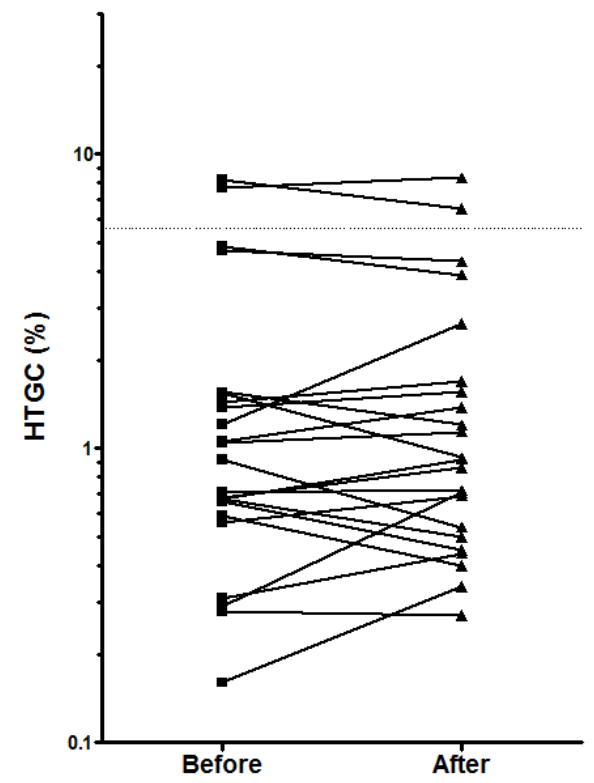

B

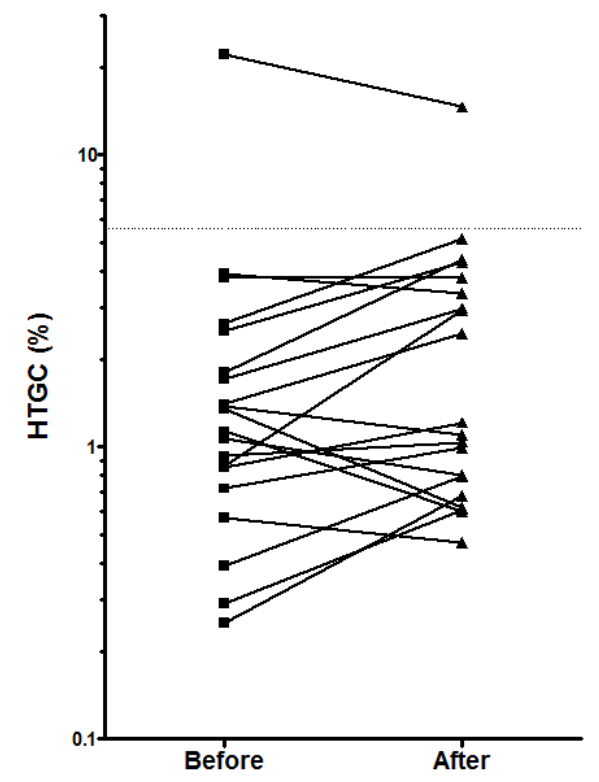

Figure 1

Effects of moderated red wine consumption on liver fat content. Levels of hepatic triglyceride content (HTGC) measured with proton nuclear magnetic resonance spectroscopy ( ${ }^{1} \mathrm{H}-\mathrm{MRS}$ ) before and after 90 days of either total alcohol abstention (A) or an intake corresponding to $150 \mathrm{ml}$ of red wine/day for women or the double amount for men (B). Observe that the y-axis is logarithmic. The dotted line represents HTGC of $5.6 \%$, i.e. the definition of hepatic steatosis.

However, when the three subjects with hepatic steatosis at baseline were excluded from analysis a trend to increased HTGC was noted within the red wine group (before median $1.1 \%$, range $0.2-3.9 \%$, after median $1.1 \%$ range $0.5-5.2 \%, \mathrm{p}=0.059)$. This difference attained statistical significance when compared with changes over time within the group of abstainers ( $\mathrm{p}=0.02$ for difference in changes between groups). Table 2 shows the same variables as Table 1 in subjects who did not have steatosis at baseline. The increases of aminotransferases and the reduction of LDL cholesterol over time within the red wine group remained statistically significant also when subjects with steatosis at baseline were excluded from analysis (Table 2). There was no change in HTGC over time, neither in the red wine group nor in the group of abstainers, when the results of men and women were analyzed separately. 


\section{Discussion}

The amount of alcohol consumption causing adverse effects on the liver is controversial (23-25). In the Dionysos study it was reported that the threshold for ALD was ingestion of $>30 \mathrm{~g}$ alcohol per day in both sexes (24). However, in that study hepatic fatty infiltration was assessed with ultrasonography, a technique that only can identify histological steatosis above $20-30 \%$ (26). Others have proposed lower thresholds, particularly in women, and generally ingestion of $20 \mathrm{~g}$ to $30 \mathrm{~g}$ of alcohol per day for men and $10 \mathrm{~g}$ to $30 \mathrm{~g}$ of alcohol per day for women has been considered to be the threshold for ALD $(23,27)$. The NIH clinical research network on NAFLD/NASH has chosen to adopt the lower thresholds ( $20 \mathrm{~g} / \mathrm{d}$ for men and $10 \mathrm{~g} / \mathrm{d}$ for women) for the definition of NAFLD (16). In the present prospective study we demonstrated that a moderate alcohol consumption which exceeds the cut-off level used in many NAFLD studies does not cause hepatic steatosis. However, a statistically significant increase of HTGC was evident in subjects without pre-existing steatosis. Interestingly, we found no correlation between alcohol consumption at baseline and HTGC. However, HTGC correlated with BMI and many biochemical parameters generally considered to associate with components of the metabolic syndrome. This suggests that HTGC is more strongly linked with obesity and insulin resistance than with alcohol intake, as was also found in the Dionysos study (28).

Interestingly, we found statistically significant changes in the levels of aminotransferases between the groups while no single participant reached a level exceeding the upper limit of normal used in Sweden either regarding ALT or AST. In contrast, our group has previously shown that hyper-alimentation during 4 weeks can induce rapid and profound elevations of ALT in conjunction with increase of HTGC 
(18). The reasons for the increased levels of aminotransferases in our study could not be ascertained, and since albumin levels were also reduced in the red wine group, some concerns regarding long-term effects of consuming moderate red wine was raised by our study, and warrant more extended prospective trials on the topic. However, it should also be emphasized that aminotransferases do not always reflect structural alterations in fatty liver disease (29).

The finding of decreased levels of serum albumin by red wine in our study is in accordance with a previous interventional study reporting a trend $(\mathrm{p}=0.07)$ towards lower serum albumin after 3 weeks daily consumption of $150 \mathrm{ml}$ red wine (30). However, a recent epidemiological study showed higher levels of serum albumin among heavy drinkers suggesting increased rates of albumin protein synthesis in response to regular ethanol intake prior to the development of hepatic dysfunction (31). Elevated plasma albumin levels have also been demonstrated to be present in alcoholics, and the albumin levels were found to correlate with the amount of protein carbonyls, suggesting that covalent modifications of proteins by acetaldehyde could also be associated with albumin protein expression in heavy drinkers (32). In vitro studies on this topic have shown elevated hepatic protein synthesis rates as a result of chronic ethanol administration in cell cultures $(33,34)$. Thus the underlying mechanisms of our finding of lowered levels of albumin by red wine are unclear, but hepatic impairment by alcohol seems unlikely since epidemiological studies suggest no such effect in heavy drinkers and that this is in line with studies of cell cultures.

ALD is one of the major causes of chronic liver disease in many Western countries and high alcohol intake induces hepatic steatosis within two weeks (35). However, when men ingested $63 \mathrm{~g}$ of ethanol daily for five weeks, analysis of liver specimens revealed 
only a transient increase in HTGC and steatosis could not be demonstrated morphologically (36). Compared with habitual alcohol consumption that is part of a regular lifestyle, the trial period of three months is a limitation of our study. However, as stated above, there is evidence that change in HTGC is a highly dynamic and quite fast process with alterations in response to alcohol taking place within weeks. It has also been shown that a moderate life-style intervention by aerobic cycling exercise 30-45 min three times a week, markedly reduced HTGC within four weeks even in the absence of body weight reduction (37).

We observed a clinically apparent reduction of LDL cholesterol by red wine, being $16 \%$ when comparing the groups at the end of the study. However, we found no effect on HDL cholesterol or insulin levels, which could have been anticipated based on earlier studies of this kind (38). The exact reasons for this are unclear but could relate to season variation since all participants were part of the study during the period of early fall to winter, or be caused by the fact that baseline levels of these variables, also including blood pressure, were favorable in most participants. Interestingly, pharmacological lowering of LDL cholesterol has more convincingly demonstrated reduction of CVD $(39,40)$ than interventions aimed at improving dyslipidemia (41) or by elevating HDL cholesterol in humans (42). Also, findings of reduction of LDL cholesterol without an effect on HDL cholesterol have been demonstrated in a 6 week study of hypercholesterolemic postmenopausal women (4). Taking into consideration that daily intake of red wine is part of the Mediterranean diet, and thus potentially can affect LDL cholesterol during several decades, our findings of a reduction of LDL cholesterol by red wine is in line with low CVD rates in Mediterranean areas. 
We did not observe any changes in body weight by the alcohol consumption despite that the caloric intake from alcohol in women exceeded $10000 \mathrm{kcal}$ in total during the three month period of the study, and a corresponding double amount in men. This could be a consequence of induction of a sense of satiety by wine. We did lack information of exact food intake, which is a shortcoming of our study. However, generally food intake data are of too poor quality to discern small changes in food intake, and systematic errors such as under-reporting in relation to BMI has been shown in food reports (43) which is why we judged it to be of little meaning to use food reports in our study.

In summary the fact that consumption of moderate amounts of alcohol for three months was related to an increase in HTGC only in subjects without liver steatosis at baseline and did not induce hepatic steatosis in a single participant should be taken into consideration in a future consistent agreement regarding which level of alcohol consumption that should be used to separate NAFLD from hepatic steatosis induced by alcohol. It is possible that the results of our study may be prone to modification by genetic factors, lifestyles and associated conditions. Thus, they may not be representative for all populations worldwide, but to our knowledge this study is presently unique and the only one that prospectively assessed the potential effect on HTGC by moderate alcohol consumption. In general we found HTGC to be stronger related to markers of increased risk for CVD than to alcohol consumption. Considering the reduced levels of LDL cholesterol by red wine in our study, and the lack of increase in body fat mass, our findings are in line with that moderate consumption of red wine could constitute an important part of the Mediterranean diet which has been shown to be linked with low prevalence of CVD (1,44-46). In the individual counseling of the patient, however, the potential benefits with regular intake of alcohol must be balanced 
against the risk for alcohol abuse, and our study only recruited subjects without a history of abuse including that of first degree relatives.

\section{Disclosure of interests}

There were no competing interests for any of the authors in relation to this manuscript.

Fredrik H Nystrom had full access to all of the data in the study and takes responsibility for the integrity of the data and the accuracy of the data analysis. 


\section{References}

1. Corrao G, Rubbiati L, Bagnardi V, Zambon A, Poikolainen K Alcohol and coronary heart disease: a meta-analysis. Addiction. 2000;95:1505-1523.

2. Reaven GM The metabolic syndrome: requiescat in pace. Clin Chem. 2005;51:931938.

3. Gottrand F, Beghin L, Duhal N, Lacroix B, Bonte JP, Fruchart JC, et al. Moderate red wine consumption in healthy volunteers reduced plasma clearance of apolipoprotein AII. Eur J Clin Invest. 1999;29:387-394.

4. Naissides M, Mamo JC, James AP, Pal S The effect of chronic consumption of red wine on cardiovascular disease risk factors in postmenopausal women. Atherosclerosis. 2006; 185:438-445.

5. Napoli R, Cozzolino D, Guardasole V, Angelini V, Zarra E, Matarazzo M, et al. Red wine consumption improves insulin resistance but not endothelial function in type 2 diabetic patients. Metabolism. 2005;54:306-313.

6. Szczepaniak LS, Nurenberg P, Leonard D, Browning JD, Reingold JS, Grundy S, et al. Magnetic resonance spectroscopy to measure hepatic triglyceride content: prevalence of hepatic steatosis in the general population. Am J Physiol Endocrinol Metab. 2005;288:E462-468.

7. Gramenzi A, Caputo F, Biselli M, Kuria F, Loggi E, Andreone P, et al. Review article: alcoholic liver disease--pathophysiological aspects and risk factors. Aliment Pharmacol Ther. 2006;24:1151-1161.

8. Ludwig J, Viggiano TR, McGill DB, Oh BJ Nonalcoholic steatohepatitis: Mayo Clinic experiences with a hitherto unnamed disease. Mayo Clin Proc. 1980;55:434438. 
9. Marchesini G, Bugianesi E, Forlani G, Cerrelli F, Lenzi M, Manini R, et al. Nonalcoholic fatty liver, steatohepatitis, and the metabolic syndrome. Hepatology. 2003;37:917-923.

10. Bedogni G, Miglioli L, Masutti F, Tiribelli C, Marchesini G, Bellentani S Prevalence of and risk factors for nonalcoholic fatty liver disease: the Dionysos nutrition and liver study. Hepatology. 2005;42:44-52.

11. Browning JD, Szczepaniak LS, Dobbins R, Nuremberg P, Horton JD, Cohen JC, et al. Prevalence of hepatic steatosis in an urban population in the United States: impact of ethnicity. Hepatology. 2004;40:1387-1395.

12. Ekstedt M, Franzen LE, Mathiesen UL, Thorelius L, Holmqvist M, Bodemar G, et al. Long-term follow-up of patients with NAFLD and elevated liver enzymes. Hepatology. 2006;44:865-873.

13. Dam-Larsen S, Franzmann M, Andersen IB, Christoffersen P, Jensen LB, Sorensen TI, et al. Long term prognosis of fatty liver: risk of chronic liver disease and death. Gut. 2004;53:750-755.

14. Garcia-Monzon C, Martin-Perez E, Iacono OL, Fernandez-Bermejo M, Majano PL, Apolinario A, et al. Characterization of pathogenic and prognostic factors of nonalcoholic steatohepatitis associated with obesity. J Hepatol. 2000;33:716-724.

15. Ratziu V, Bellentani S, Cortez-Pinto H, Day C, Marchesini G A position statement on NAFLD/NASH based on the EASL 2009 special conference. J Hepatol. 2010;53:372-384.

16. Farrell GC, Larter CZ Nonalcoholic fatty liver disease: from steatosis to cirrhosis. Hepatology. 2006;43:S99-S112.

17. Bush K, Kivlahan DR, McDonell MB, Fihn SD, Bradley KA The AUDIT alcohol consumption questions (AUDIT-C): an effective brief screening test for problem 
drinking. Ambulatory Care Quality Improvement Project (ACQUIP). Alcohol Use Disorders Identification Test. Arch Intern Med. 1998;158:1789-1795.

18. Kechagias S, Ernersson A, Dahlqvist O, Lundberg P, Lindstrom T, Nystrom FH Fast-food-based hyper-alimentation can induce rapid and profound elevation of serum alanine aminotransferase in healthy subjects. Gut. 2008;57:649-654.

19. Naressi A, Couturier C, Devos JM, Janssen M, Mangeat C, de Beer R, et al. Javabased graphical user interface for the MRUI quantitation package. MAGMA. 2001;12:141-152.

20. Vanhamme L, van den Boogaart A, Van Huffel S Improved method for accurate and efficient quantification of MRS data with use of prior knowledge. J Magn Reson. 1997;129:35-43.

21. Bonora E, Targher G, Alberiche M, Bonadonna RC, Saggiani F, Zenere MB, et al. Homeostasis model assessment closely mirrors the glucose clamp technique in the assessment of insulin sensitivity: studies in subjects with various degrees of glucose tolerance and insulin sensitivity. Diabetes Care. 2000;23:57-63.

22. Katz A, Nambi SS, Mather K, Baron AD, Follmann DA, Sullivan G, et al. Quantitative insulin sensitivity check index: a simple, accurate method for assessing insulin sensitivity in humans. J Clin Endocrinol Metab. 2000;85:2402-2410.

23. Becker U, Deis A, Sorensen TI, Gronbaek M, Borch-Johnsen K, Muller CF, et al. Prediction of risk of liver disease by alcohol intake, sex, and age: a prospective population study. Hepatology. 1996;23:1025-1029.

24. Bellentani S, Saccoccio G, Costa G, Tiribelli C, Manenti F, Sodde M, et al. Drinking habits as cofactors of risk for alcohol induced liver damage. The Dionysos Study Group. Gut. 1997;41:845-850. 
25. Norton R, Batey R, Dwyer T, MacMahon S Alcohol consumption and the risk of alcohol related cirrhosis in women. Br Med J (Clin Res Ed). 1987;295:80-82.

26. Saadeh S, Younossi ZM, Remer EM, Gramlich T, Ong JP, Hurley M, et al. The utility of radiological imaging in nonalcoholic fatty liver disease. Gastroenterology. 2002;123:745-750.

27. Thun MJ, Peto R, Lopez AD, Monaco JH, Henley SJ, Heath CW, Jr., et al. Alcohol consumption and mortality among middle-aged and elderly U.S. adults. N Engl J Med. 1997;337:1705-1714.

28. Bellentani S, Saccoccio G, Masutti F, Croce LS, Brandi G, Sasso F, et al. Prevalence of and risk factors for hepatic steatosis in Northern Italy. Ann Intern Med. 2000;132:112-117.

29. Fracanzani AL, Valenti L, Bugianesi E, Andreoletti M, Colli A, Vanni E, et al. Risk of severe liver disease in nonalcoholic fatty liver disease with normal aminotransferase levels: a role for insulin resistance and diabetes. Hepatology. 2008;48:792-798.

30. Retterstol L, Berge KE, Braaten O, Eikvar L, Pedersen TR, Sandvik L A daily glass of red wine: does it affect markers of inflammation? Alcohol Alcohol. 2005;40:102105.

31. Alatalo P, Koivisto H, Puukka K, Hietala J, Anttila P, Bloigu R, et al. Biomarkers of liver status in heavy drinkers, moderate drinkers and abstainers. Alcohol Alcohol. 2009;44:199-203.

32. Tyulina OV, Prokopieva VD, Boldyrev AA, Johnson P Erythrocyte and plasma protein modification in alcoholism: a possible role of acetaldehyde. Biochim Biophys Acta. 2006;1762:558-563. 
33. Ohtake H, Kato S, Murawaki Y, Kishimoto Y, Wakushima T, Hirayama C Acute and chronic effect of ethanol on hepatic albumin synthesis in rat liver in vitro. Res Commun Chem Pathol Pharmacol. 1986;53:213-231.

34. Rothschild MA, Oratz M, Schreiber SS Serum albumin. Hepatology. 1988;8:385401.

35. Schapiro RH, Scheig RL, Drummey GD, Mendelson JH, Isselbacher KJ Effect of Prolonged Ethanol Ingestion on the Transport and Metabolism of Lipids in Man. N Engl J Med. 1965;272:610-615.

36. Belfrage P, Berg B, Cronholm T, Elmqvist D, Hagerstrand I, Johansson B, et al. Prolonged administration of ethanol to young, healthy volunteers: effects on biochemical, morphological and neurophysiological parameters. Acta Med Scand Suppl. 1973;552:1-44.

37. Johnson NA, Sachinwalla T, Walton DW, Smith K, Armstrong A, Thompson MW, et al. Aerobic exercise training reduces hepatic and visceral lipids in obese individuals without weight loss. Hepatology. 2009;50:1105-1112.

38. Kawano Y Physio-pathological effects of alcohol on the cardiovascular system: its role in hypertension and cardiovascular disease. Hypertens Res. 2010;33:181-191.

39. Rouleau J Improved outcome after acute coronary syndromes with an intensive versus standard lipid-lowering regimen: results from the Pravastatin or Atorvastatin Evaluation and Infection Therapy-Thrombolysis in Myocardial Infarction 22 (PROVE IT-TIMI 22) trial. Am J Med. 2005;118 Suppl 12A:28-35.

40. MRC/BHF Heart Protection Study of cholesterol lowering with simvastatin in 20,536 high-risk individuals: a randomised placebo-controlled trial. Lancet. $2002 ; 360: 7-22$ 
41. Keech A, Simes RJ, Barter P, Best J, Scott R, Taskinen MR, et al. Effects of longterm fenofibrate therapy on cardiovascular events in 9795 people with type 2 diabetes mellitus (the FIELD study): randomised controlled trial. Lancet. 2005;366:1849-1861.

42. Kastelein JJ, van Leuven SI, Burgess L, Evans GW, Kuivenhoven JA, Barter PJ, et al. Effect of torcetrapib on carotid atherosclerosis in familial hypercholesterolemia. N Engl J Med. 2007;356:1620-1630.

43. Lof M, Forsum E Validation of energy intake by dietary recall against different methods to assess energy expenditure. J Hum Nutr Diet. 2004;17:471-480.

44. Renaud S, de Lorgeril M, Delaye J, Guidollet J, Jacquard F, Mamelle N, et al. Cretan Mediterranean diet for prevention of coronary heart disease. Am J Clin Nutr. $1995 ; 61: 1360 \mathrm{~S}-1367 \mathrm{~S}$.

45. Shai I, Schwarzfuchs D, Henkin Y, Shahar DR, Witkow S, Greenberg I, et al. Weight loss with a low-carbohydrate, Mediterranean, or low-fat diet. N Engl J Med. 2008;359:229-241.

46. Marfella R, Cacciapuoti F, Siniscalchi M, Sasso FC, Marchese F, Cinone F, et al. Effect of moderate red wine intake on cardiac prognosis after recent acute myocardial infarction of subjects with Type 2 diabetes mellitus. Diabet Med. 2006;23:974-981. 
Table 1.

Effects of moderate red wine consumption on cardiovascular risk factors, liver function tests and hepatic triglyceride content in the total cohort. Anthropometric and laboratory data before and after randomization to total abstention from alcohol or consumption of $150 \mathrm{ml}$ red wine/day for women or $300 \mathrm{ml} /$ day for men. Figures are means (SD) except for HTGC where median and range are also given. All laboratory variables were measured in the fasting state. There were no differences between the levels of the variables between the two groups at baseline.

\begin{tabular}{|c|c|c|c|c|c|c|c|}
\hline Variable & $\begin{array}{l}\text { Baseline } \\
\text { total } \\
\text { abstention }\end{array}$ & $\begin{array}{l}\text { Three } \\
\text { months of } \\
\text { total } \\
\text { abstention }\end{array}$ & $\begin{array}{l}\mathrm{P} \text { value } \\
\text { for } \\
\text { changes } \\
\text { after } \\
\text { total } \\
\text { abstention }\end{array}$ & $\begin{array}{l}\text { Baseline red } \\
\text { wine group }\end{array}$ & $\begin{array}{l}\text { Three } \\
\text { months of } \\
\text { red wine } \\
\text { consumption }\end{array}$ & $\begin{array}{l}\text { P value } \\
\text { for } \\
\text { changes } \\
\text { after } \\
\text { red wine }\end{array}$ & $\begin{array}{l}\text { P value } \\
\text { for } \\
\text { difference } \\
\text { between } \\
\text { changes } \\
\text { in the } \\
\text { groups }\end{array}$ \\
\hline Age (yr) & $34(9)$ & & & $33(9)$ & & & \\
\hline $\operatorname{Sex}(\mathrm{M} / \mathrm{F})$ & $5 / 18$ & & & $7 / 14$ & & & \\
\hline Weight (kg) & $68.8(15)$ & $68.4(15)$ & 0.20 & $73.5(9.0)$ & $73.3(9.6)$ & 0.82 & 0.65 \\
\hline $\begin{array}{l}\text { Body-mass } \\
\text { index } \\
\left(\mathrm{kg} / \mathrm{m}^{2}\right)\end{array}$ & $23.3(4.2)$ & $23.2(4.3)$ & 0.20 & $25.0(3.4)$ & $24.9(3.7)$ & 0.87 & 0.64 \\
\hline $\begin{array}{l}\text { Glucose } \\
(\mathrm{mmol} / \mathrm{l})\end{array}$ & $5.2(0.5)$ & $5.3(0.5)$ & 0.90 & $5.3(0.6)$ & $5.5(0.6)$ & 0.02 & 0.20 \\
\hline $\begin{array}{l}\text { Insulin } \\
(\mathrm{pmol} / \mathrm{l})\end{array}$ & $38.8(20)$ & $43.3(24)$ & 0.19 & $41.9(18)$ & $46.7(23)$ & 0.20 & 0.95 \\
\hline HOMA & $1.4(0.7)$ & $1.5(0.9)$ & 0.24 & $1.4(0.7)$ & $1.7(0.9)$ & 0.13 & 0.75 \\
\hline $\begin{array}{l}\text { Total } \\
\text { cholesterol } \\
(\mathrm{mmol} / \mathrm{l})\end{array}$ & $5.5(1.4)$ & $5.5(1.4)$ & 0.95 & $5.0(1.0)$ & $4.8(1.0)$ & 0.086 & 0.25 \\
\hline $\begin{array}{l}\text { LDL } \\
\text { cholesterol } \\
(\mathrm{mmol} / \mathrm{l})\end{array}$ & $3.2(1.1)$ & $3.2(1.2)$ & 0.68 & $3.0(0.9)$ & $2.7(0.9)$ & 0.008 & 0.031 \\
\hline $\begin{array}{l}\text { HDL } \\
\text { cholesterol } \\
(\mathrm{mmol} / \mathrm{l})\end{array}$ & $1.9(0.54)$ & $1.8(0.5)$ & 0.32 & $1.6(0.4)$ & $1.6(0.4)$ & 0.97 & 0.44 \\
\hline $\begin{array}{l}\text { Triglycerides } \\
(\mathrm{mmol} / \mathrm{l})\end{array}$ & $1.2(1.3)$ & $0.9(0.38)$ & 0.29 & $0.9(0.41)$ & $1.1(0.54)$ & 0.11 & 0.15 \\
\hline ApoB (g/l) & $1.0(0.3)$ & $1.0(0.3)$ & 0.91 & $0.9(0.2)$ & $0.9(0.2)$ & 0.061 & 0.16 \\
\hline $\operatorname{ApoA1}(\mathrm{g} / \mathrm{l})$ & $1.6(0.3)$ & $1.5(0.3)$ & 0.007 & $1.5(0.2)$ & $1.4(0.22)$ & 0.071 & 0.31 \\
\hline ALT (U/l) & $21(8)$ & $19(8)$ & 0.061 & $21(9)$ & $24(10)$ & 0.16 & 0.022 \\
\hline AST (U/l) & $25(6)$ & $24(4)$ & 0.29 & $23(4)$ & $26(6)$ & 0.005 & 0.006 \\
\hline
\end{tabular}




\begin{tabular}{|c|c|c|c|c|c|c|c|}
\hline AST/ALT & $1.2(0.4)$ & $1.3(0.3)$ & 0.16 & $1.2(0.4)$ & $1.2(0.4)$ & 0.60 & 0.56 \\
\hline ALP (U/1) & $47(11)$ & $49(15)$ & 0.48 & $56(13)$ & 53 (19) & 0.41 & 0.28 \\
\hline GT (U/l) & $18(7)$ & $23(12)$ & 0.45 & $22(11)$ & $21(13)$ & 0.75 & 0.39 \\
\hline $\begin{array}{l}\text { Bilirubin } \\
(\mathrm{mg} / \mathrm{dl})\end{array}$ & $0.7(0.3)$ & $0.7(0.3)$ & 0.62 & $0.7(0.2)$ & $0.6(0.3)$ & 0.31 & 0.70 \\
\hline $\begin{array}{l}\text { Albumin } \\
(\mathrm{g} / \mathrm{dl})\end{array}$ & $4.4(0.4)$ & $4.4(0.4)$ & 0.96 & $4.5(0.4)$ & $4.3(0.33)$ & $<0.0001$ & 0.023 \\
\hline $\begin{array}{l}\text { Hepatic } \\
\text { triglyceride } \\
\text { content }(\%) \\
\text { mean values } \\
\text { and median } \\
\text { (range) }\end{array}$ & $\begin{array}{l}1.8(2.3) \\
0.9(0.2-8.2)\end{array}$ & $\begin{array}{l}1.8(2.1) \\
0.9(0.3-8.3)\end{array}$ & $\begin{array}{l}0.80 \\
1.0\end{array}$ & $\begin{array}{l}2.5(4.7) \\
1.2(0.3- \\
22.1)\end{array}$ & $\begin{array}{l}2.6(3.2) \\
1.2(0.5- \\
14.6)\end{array}$ & $\begin{array}{l}0.74 \\
0.17\end{array}$ & $\begin{array}{l}0.67 \\
0.17\end{array}$ \\
\hline Body fat (\%) & $28.6(10)$ & $28.4(10)$ & 0.58 & $28.8(11)$ & $29.3(11)$ & 0.31 & 0.24 \\
\hline
\end{tabular}

Abbreviations: ALT, alanine aminotransferase; AST, aspartate aminotransferase; ALP, alkaline phosphatase, GT, gamma-glutamyl transpeptidase. Conversions: glucose (mg/dL) x $0.055=\mathrm{mmol} / \mathrm{L}$, Insulin $(\mu \mathrm{IU} / \mathrm{ml}) \times 6.94=\mathrm{pmol} / \mathrm{L}$, cholesterol, HDL, and LDL $(\mathrm{mg} / \mathrm{dL}) \mathrm{x}$ $0.026=\mathrm{mmol} / \mathrm{L}$, triglycerides $(\mathrm{mg} / \mathrm{dL}) \times 0.011=\mathrm{mmol} / \mathrm{L}$, ALT, AST, ALP, GT $(\mathrm{U} / \mathrm{l}) \times 0.017$ $=\mu \mathrm{kat} / \mathrm{l}$, bilirubin $(\mathrm{mg} / \mathrm{dl}) \times 17.1=\mu \mathrm{mol} / \mathrm{l}, \operatorname{albumin}(\mathrm{g} / \mathrm{dl}) \times 10=\mathrm{g} / 1$. 
Table 2.

Effects of moderate red wine consumption on cardiovascular risk factors, liver function tests and hepatic triglyceride content in participants without hepatic steatosis at baseline.

Anthropometric and laboratory data before and after randomization to total abstention from alcohol or consumption of $150 \mathrm{ml}$ red wine/day for women or $300 \mathrm{ml} /$ day for men in participants with HTGC $<5.6 \%$ at baseline. Figures are means (SD) except for HTGC where median and range are also given. All laboratory variables were measured in the fasting state.

\begin{tabular}{|c|c|c|c|c|c|c|c|}
\hline Variable & $\begin{array}{l}\text { Baseline } \\
\text { total } \\
\text { abstention }\end{array}$ & $\begin{array}{l}\text { Three } \\
\text { months of } \\
\text { total } \\
\text { abstention }\end{array}$ & $\begin{array}{l}\mathrm{P} \text { value } \\
\text { for } \\
\text { changes } \\
\text { by } \\
\text { total } \\
\text { abstention }\end{array}$ & $\begin{array}{l}\text { Baseline red } \\
\text { wine group }\end{array}$ & $\begin{array}{l}\text { Three } \\
\text { months of } \\
\text { red wine } \\
\text { consumption }\end{array}$ & $\begin{array}{l}\text { P value } \\
\text { for } \\
\text { changes } \\
\text { by } \\
\text { red wine }\end{array}$ & $\begin{array}{l}\text { P value } \\
\text { for } \\
\text { difference } \\
\text { between } \\
\text { changes } \\
\text { in the } \\
\text { groups }\end{array}$ \\
\hline Age (yr) & $34(8)$ & & & $32(8)$ & & & \\
\hline $\operatorname{Sex}(M / F)$ & $4 / 17$ & & & $7 / 13$ & & & \\
\hline Weight (kg) & $67.6(14.6)$ & $67.2(14.6)$ & 0.17 & $72.8(8.6)$ & $72.8(9.5)$ & 0.98 & 0.49 \\
\hline $\begin{array}{l}\text { Body-mass } \\
\text { index } \\
\left(\mathrm{kg} / \mathrm{m}^{2}\right)\end{array}$ & $22.9(4.2)$ & $22.8(4.2)$ & 0.17 & $24.6(3.1)$ & $24.6(3.5)$ & 0.92 & 0.47 \\
\hline $\begin{array}{l}\text { Glucose } \\
(\mathrm{mmol} / \mathrm{l})\end{array}$ & $5.3(0.5)$ & $5.3(0.5)$ & 0.9 & $5.2(0.5)$ & $5.4(0.5)$ & 0.06 & 0.23 \\
\hline $\begin{array}{l}\text { Insulin } \\
(\mathrm{pmol} / \mathrm{l})\end{array}$ & $39(20)$ & $43(24)$ & 0.19 & $41(17)$ & $46(23)$ & 0.13 & 0.80 \\
\hline HOMA & $1.3(0.7)$ & $1.5(0.9)$ & 0.24 & $1.3(0.5)$ & $1.5(0.7)$ & 0.12 & 0.72 \\
\hline $\begin{array}{l}\text { Total } \\
\text { cholesterol } \\
(\mathrm{mmol} / \mathrm{l})\end{array}$ & $5.4(1.4)$ & $5.3(1.3)$ & 0.9 & $4.9(0.8)$ & $4.7(0.9)$ & 0.15 & 0.39 \\
\hline $\begin{array}{l}\text { LDL } \\
\text { cholesterol } \\
(\mathrm{mmol} / \mathrm{l})\end{array}$ & $3.1(1.1)$ & $3.1(1.2)$ & 0.88 & $2.9(0.8)$ & $2.6(0.8)$ & 0.01 & 0.06 \\
\hline $\begin{array}{l}\text { HDL } \\
\text { cholesterol } \\
(\mathrm{mmol} / \mathrm{l})\end{array}$ & $1.9(0.6)$ & $1.8(0.5)$ & 0.27 & $1.6(0.4)$ & $1.6(0.4)$ & 0.78 & 0.30 \\
\hline $\begin{array}{l}\text { Triglycerides } \\
(\mathrm{mmol} / \mathrm{l})\end{array}$ & $1.2(1.3)$ & $0.9(0.4)$ & 0.37 & $0.9(0.4)$ & $1.1(0.5)$ & 0.047 & 0.16 \\
\hline ApoB (g/l) & $1.0(0.3)$ & $1.0(0.3)$ & 0.86 & $0.9(0.2)$ & $0.9(0.2)$ & 0.10 & 0.30 \\
\hline ApoA1 (g/l) & $1.6(0.3)$ & $1.5(0.3)$ & 0.10 & $1.5(0.2)$ & $1.4(0.2)$ & 0.10 & 0.25 \\
\hline ALT (U/l) & $20(7)$ & $18(5)$ & 0.05 & $20(6)$ & $22(9)$ & 0.08 & 0.009 \\
\hline AST (U/1) & $25(6)$ & $24(4)$ & 0.37 & $22(4)$ & $25(6)$ & 0.004 & 0.007 \\
\hline ALP (U/l) & $48(12)$ & $50(15)$ & 0.30 & $55(12)$ & $55(14)$ & 0.98 & 0.28 \\
\hline
\end{tabular}




\begin{tabular}{|l|l|l|l|l|l|l|l|}
\hline GT (U/l) & $18(6)$ & $23(11)$ & 0.45 & $16(6)$ & $18(4)$ & 0.15 & 0.22 \\
\hline $\begin{array}{l}\text { Bilirubin } \\
(\mathrm{mg} / \mathrm{dl})\end{array}$ & $0.7(0.4)$ & $0.7(0.3)$ & 0.59 & $0.7(0.2)$ & $0.6(0.4)$ & 0.31 & 0.73 \\
\hline $\begin{array}{l}\text { Albumin } \\
(\mathrm{g} / \mathrm{dl})\end{array}$ & $4.4(0.4)$ & $4.4(0.4)$ & 0.84 & $4.5(0.4)$ & $4.3(0.3)$ & 0.001 & 0.02 \\
\hline $\begin{array}{l}\text { Hepatic } \\
\text { triglyceride } \\
\text { content (\%) }\end{array}$ & $0.7(0.2-4.9)$ & $0.9(0.3-4.3)$ & 0.96 & $1.1(0.2-3.9)$ & $1.1(0.5-5.2)$ & 0.059 & 0.02 \\
\hline Body fat (\%) & $28(10)$ & $28(10)$ & 0.69 & $28(10)$ & $29(11)$ & 0.29 & 0.27 \\
\hline
\end{tabular}

Abbreviations: ALT, alanine aminotransferase; AST, aspartate aminotransferase; ALP, alkaline phosphatase, GT, gamma-glutamyl transpeptidase. Conversions: glucose (mg/dL) x $0.055=\mathrm{mmol} / \mathrm{L}$, Insulin $(\mu \mathrm{IU} / \mathrm{ml}) \times 6.94=\mathrm{pmol} / \mathrm{L}$, cholesterol, HDL, and LDL $(\mathrm{mg} / \mathrm{dL}) \times$ $0.026=\mathrm{mmol} / \mathrm{L}$, triglycerides $(\mathrm{mg} / \mathrm{dL}) \times 0.011=\mathrm{mmol} / \mathrm{L}$, ALT, AST, ALP, GT $(\mathrm{U} / \mathrm{l}) \times 0.017$

$=\mu \mathrm{kat} / \mathrm{l}$, bilirubin $(\mathrm{mg} / \mathrm{dl}) \times 17.1=\mu \mathrm{mol} / \mathrm{l}$, albumin $(\mathrm{g} / \mathrm{dl}) \times 10=\mathrm{g} / \mathrm{l}$. 